This is an open access article under the CC BY-NC-ND license

Issue IV, 22 November 2021

e-ISSN 2707-9481

Institute of Metallurgy and Ore Beneficiation, Satbayev University, Almaty, Kazakhstan

ISBN 978-601-323-252-2

https://doi.org/10.31643/2021.03

Janu Arlinwibowo

Universitas Muhammadiyah Kudus,

Central Java, Indonesia

E-mail: janu@umkudus.ac.id

ORCID ID 0000-0001-9566-9468
Heri Retnawati

Mathematics and Science Faculty,

Universitas Negeri Yogyakarta, Indonesia

E-mail: heri retnawati@uny.ac.id

ORCID ID 0000-0002-1792-5873

\author{
Badrun Kartowagiran \\ Prost Graduate Program, \\ Universitas Negeri Yogyakarta, Indonesia \\ E-mail: kartowagiran@uny.ac.id \\ ORCID ID 0000-0002-8536-5417
}

\title{
How to Integrate STEM Education in The Indonesian Curriculum? A Systematic Review
}

\begin{abstract}
STEM education has received a lot of attention, including in Indonesia, because it is considered capable of preparing competitive students in the 21st century. However, the implementation of STEM learning is constrained because there are no standard guidelines according to the curriculum 2013 (education curriculum in Indonesia). Therefore, the aim of this study is to find an integration formula for STEM learning and the curriculum 2013 based on the synthesis of various literature to find a formula for implementing STEM learning in accordance with the curriculum 2013. This study is a systematic review. The data sources in this research are 46 selected literatures and relevant to the research objectives published between 1996 and 2020 . The data sources are literature published in ISBN books, government documents, and journals. The data collected from the literature were analyzed with a thematic model starting with data introduction, initial coding, compiling code within a theme, analyzing themes, naming themes, and relating findings to research questions. The research resulted in a learning step that combines EDP in STEM, the scientific approach in the 2013 curriculum, and project learning steps. The merger produces a guideline for implementing STEM learning in the 2013 curriculum starting from problem identification, making problem-solving designs, design realization, testing and studying product deficiencies, improving products, drawing conclusions, and communicating the findings of the learning process.
\end{abstract}

Keywords: STEM Education, Indonesia, Curriculum, Teaching Activity.

Cite this article as: Arlinwibowo, J., Retnawati, H., \& Kartowagiran, B. (2021). How to Integrate STEM Education in Indonesian Curriculum? A Systematic Review. Challenges of Science. Issue IV, 2021, pp. 18-25. https://doi.org/10.31643/2021.03

\section{Introduction}

The development of technology in this century is going very fast (Arlinwibowo, Retnawati, Hadi, Kartowagiran, \& Kassymova, 2021; Marsigit et al., 2020). This makes a significant difference from the previous era (Arlinwibowo, Retnawati, Kartowagiran, \& Kassymova, 2020). This condition has been responded to by many experts that formulating the skills needed in this century. By elaborating many expert opinions and observing the social condition of the country, the Ministry of Education and Culture of the Republic of Indonesia made a standard guideline for the implementation of 21st century education which was formulated as the Indonesian Partnership for 21 Century Skill Standard (IP-21CSS). The standard directs the implementation of education to be oriented to 21st century skills (creativity and innovation, critical thinking and problem solving, communication, and collaboration) coupled with the use of ICT, 
character education development, and emphasis on spiritual values (Ariyana, Pudjiastuti, Bestary, \& Zamroni, 2018).

Education is required to make transformations in order to be able to develop students' abilities in accordance with the formulation of abilities that must be mastered at this time (Arlinwibowo, Retnawati, \& Kartowagiran, 2020). The educational approach for students in Science, Technology, Engineering, and Mathematics (STEM) has received increasing attention over the past decade (Honey, Pearson, \& Schweingruber, 2014). STEM is considered to be able to align the education process with the demands of the times. In this era the problems faced are increasingly complex and integrative learning STEM is felt to be very suitable with these conditions (Roehrig, Wang, Moore, \& Park, 2012) because the real problem is indeed not fragmented in the barriers of scientific discipline (Beane, 1995; Czerniak, Weber, Sandmann, \& Ahern, 1999). With integrative learning, student experiences become more relevant to real life (Furner \& Kumar, 2007).

The STEM approach began to develop in Indonesia (Arlinwibowo, Retnawati, \& Badrun, 2020). In the academic environment, several studies have been conducted to try to search for the effects of STEM implementation in learning. Some research results show that there is a positive correlation between STEM implementation and the quality of student learning outcomes (Khaeroningtyas, Permanasari, \& Hamidah, 2016; Putra, 2017; Wisudawati, 2018). In the environment of policy makers and education providers, STEMbased learning training has often begun through the Ministry of Education and Culture, the Center for Development and Empowerment of Educators and Personnel (PPPPTK), SEAMEO QITEP, and universities.

However, education institutions must not implement the concept of learning in a hurry. Learning must still adjust to the applicable curriculum. The 2013 curriculum has the characteristics of scientific learning (Ariyana et al., 2018) and STEM has an engineering design process identity (Kelley \& Knowles, 2016). Both of them have specific learning steps. On the other hand, there are similarities, STEM is identical to the project (Chesky \& Wolfmeyer, 2015) while the 2013 curriculum mandates project-based learning to be one of the learning models (Ariyana et al., 2018). At present, there is no reference that clearly shows the mixing of the two. Thus, this study aims to synthesize a variety of literature in order to find a formula for STEM student delivery in accordance with the 2013 curriculum.

\section{Research Methodology}

This research is a systematic review carried out to conduct a basic study of STEM education implementation in accordance with the curriculum in Indonesia. Researchers compile research results from various journals, theories, and expert opinions contained in a variety of relevant books, handbooks issued by the Indonesian government, and legislation in force in Indonesia. Researchers focus on collecting various literature related to STEM, integrative education, thematic education, project-based learning, and the curriculum 2013 as a curriculum that currently applies in Indonesia. There are 46 selected pieces of literature which will then be used as basic analysis.

The process of screening literature is carried out by taking into account several criteria, namely (1) published between 1996 and 2019, (2) articles are published in a journal, books have ISBNs, and government documents have been authorized by authorized officials or downloaded from official government pages, (4) the substance in the literature accordingly can assist researchers in solving research questions.

Analysis of the results uses thematic analysis for identifying, analyzing, and reporting themes on a data set. According to Braun \& Clarke (2006), to carry out thematic analysis, the six phases in thematic analytics are recognizing data, making initial code on data, compiling code to look for themes, examining themes, defining and naming themes, and ending the report of themes by linking them back it to the research question.

\section{STEM Education}

The most common implementation of learning is subject fragmentation. Subjects are taught separately without any focus on the relationship between subjects (Green, 2014), this phenomenon also occurs in Indonesia. The STEM approach emphasizes that fragmentation of subjects must be minimized, 
especially in disciplines related to science, technology, engineering, and mathematics. The four STEM fields are inherently related so that it will benefit students to learn through contextual projects according to the demands of the times (Chesky \& Wolfmeyer, 2015).

The STEM approach is formulated in education with the aim of improving the quality of graduates in global competition. STEM education is a method of learning techniques in teaching the STEM discipline (Ntemngwa \& Oliver, 2018). Integrated STEM learning is classroom management (Wisudawati, 2018) and a pedagogical approach of integrating two or more STEM disciplines in a project (Ntemngwa \& Oliver, 2018) in authentic contexts to enhance student learning quality (Kelley \& Knowles, 2016). Roehrig et al., (2012) said that STEM integration is an approach that builds natural relationships between STEM domains to enhance student understanding in each discipline, make learning more interesting, and expand understanding through relevant contexts. Kanematsu \& Barry (2016) state that STEM learning combines STEM disciplines with creativity at all levels of education, formal and informal. Rosicka (2016) believes that STEM education is the umbrella of the STEM domain that is taught collectively with an interdisciplinary approach so as to improve critical thinking skills and problem solving.

STEM education aims to prepare students to be able to compete in the 21st century. Through STEM education, 21st century skills that are critical thinking, creativity, communication skills, collaboration, and independence can be developed through integrated project-based learning (Bybee, 2010). In terms of substance, STEM education aims to find connections between STEM subjects and provide relevant context for learning content (Kelley \& Knowles, 2016). In terms of students, STEM education implementation aims to (a) deepen students' understanding of concepts; (b) broadening student understanding through exposure to STEM contexts that are relevant to society and culture; and (c) increasing interest in the STEM discipline and expanding the path for students to enter the STEM field (Roehrig et al., 2012).

Thus it can be concluded that integrated STEM education is a methodical approach to integrating two or more STEM disciplines in one contextual project to mastery 21st century competencies such as problem solving skills, critical thinking, innovation ability, creative thinking, communication, and collaboration.

Picture 1. Illustration of STEM Learning (Kelley \& Knowles, 2016)

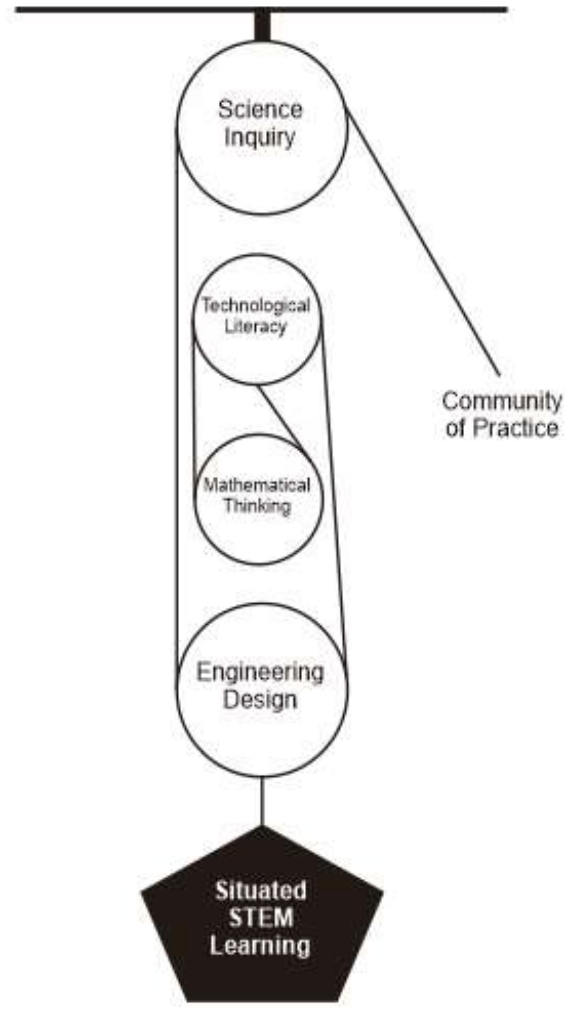

According to Bryan, Moore, Johnson, \& Roehrig one of the characteristics of integrated STEM learning is the practice of engineering and design of technological engineering as a planned process that 
involves the use of scientific and mathematical concepts through the justification of the design (Shahali, Halim, Rasul, Osman, \& Zulkifeli, 2017). STEM integration can occur in various ways in combining STEM disciplines such as emphasizing one discipline more than another, serving informal, non-formal, or informal settings, and involving various pedagogical strategies (Honey et al., 2014). The integrated STEM approach uses real-world contexts to investigate authentic problems using active learning (Hernandez et al., 2014) which leads to increased motivation, and increased achievement in science and mathematics (Furner \& Kumar, 2007). The application of the STEM approach to learning also requires a student-centered learning model (Corlu, 2013). Thus it is logical if Herschbach states that an integrated curriculum can improve the quality of learning and make science more relevant to the real world (Green, 2014). (Kelley \& Knowles, 2016) describe STEM in a series of pulleys as in picture 1.

The picture shows that the learning process is something that must be raised. The technique of converting natural resources (science and mathematics) so that it can be utilized by humans (Barak, 2012). Engineering design can provide an ideal STEM content integrator (Katehi, Pearson, \& Feder, 2009). In addition, engineering design combines engineering practices so as to bring all four disciplines into harmony. The nature of engineering design uses a systematic approach to solving problems in all areas of STEM (Kelley \& Knowles, 2016). Technical design in learning is carried out by asking questions, imagine, design (plan), create, and improvements (Lachapelle \& Cunningham, 2007; Syukri, Halim, \& Mohtar, 2017). But Susan \& Delaney (2011) adds an experimental step between the process of testing and improving.

Science is based on certain principles, including empirical evidence and understanding that science is in a context. Science is in-depth and extensive content knowledge (NBPTS, 2016). Science has the ability to transfer scientific knowledge to an authentic situation so that it can be understood. Science learning requires teachers who are able to encourage the development of scientific inquiry skills, curiosity, and openness to new ideas. Scientific inquiry trains students to think and act like scientists, formulate questions, draw hypotheses, and conduct investigations with practice (Kelley \& Knowles, 2016).

Technology has a close relationship with engineering. Technology is the home of engineering, where engineering is the process of producing technological products. Practically, technology can increase productivity and effectiveness through the manipulation of knowledge (Barak, 2012). Technology is a process that includes designing, making, and using technology to overcome various problems (Kelley \& Knowles, 2016; Kenzhaliyev et al., 2014; Kenzhaliyev et al., 2017; Kassymova, 2018). Technology literacy is the ability to use, manage, assess, and understand technology (Zinn, 2014). STEM educators must provide opportunities for students to think through technology as tools for change with positive impacts on culture, society, politics, economics, and the environment (Kelley \& Knowles, 2016). Only by learning technology, students can utilize technology.

The last pulley is mathematical thinking. Burghardt and Hackers state that mathematics is a tool to evaluate patterns and solutions rationally (Kelley \& Knowles, 2016). NCTM (2000) provides the formulation of the importance of mathematics, namely (1) Mathematics for life, that is, life is increasingly closely linked to a mathematical pattern. (2) Mathematics as a part of cultural heritage is the result of culture. Many historical relics are documented with mathematical patterns. (3) Mathematics for the workplace that is the world of work really needs a mathematician in modeling various problems. (4) Mathematics for the scientific and technical community that is all fields of science require mathematics in processing information and drawing conclusions.

Thus, in each discipline STEM has its own role in a real problem. The key problem profile at this time is (1) the cause and effect can be explained by science, (2) the patterns of events can be concluded by mathematics, (3) designing a solution to the problem can be done by the engineering, and (4) technology becomes a product as a tool or the result of a problem solving project. To guarantee the implementation of STEM learning, a learning step formula is needed. EDP is a step in the learning process that can guide the STEM learning process so that learning objectives can be achieved.

\section{Integrated Education}

The integration is used to describe the nature of the relationship between two or more disciplines included in an interdisciplinary unit. The point to note is that the learning process is carried out based on careful planning and runs on a certain theme by keeping in mind the graduation standards set in each 
discipline. The focus of learning is to provide a correlation between knowledge and context in an idea (Gehrke, 1998; Lonning, Defranco, \& Weinland, 1998). Drake \& Burns (2004) states that integrated education is a concept where connections between disciplines (skills and knowledge). The keyword of an integrated curriculum is a collective effort for each form of curriculum that deliberately connects various sciences from various disciplines of study into a unity of knowledge (Fu \& Sibert, 2017).

Drake \& Burns (2004) divides integration education into three types of approaches namely multidisciplinary, interdisciplinary, and transdisciplinary. The multidisciplinary curriculum has the same theme or the same ability in various disciplines, but each subject is still different and separate. For example, the theme of "identity" can be explored in geography (mapping), history (nationality), literature (characterization), science (classification), and so on (Drake \& Reid, 2018). In an interdisciplinary approach, the curriculum governs general learning across disciplines. The curriculum divides general learning that is embedded in scientific disciplines to emphasize interdisciplinary skills and concepts. Each other can be identified, but not considered as urgent as in a multidisciplinary approach (Drake \& Burns, 2004). The transdisciplinary curriculum goes beyond scientific disciplines. Learning focuses on pressing questions, problems, or problems so the subject is mixed holistically. There may be focused attention on developing relevant capabilities (Drake \& Reid, 2018).

Real-world problems are not fragmented and thus require skills that cross disciplines (Beane, 1995; Czerniak et al., 1999). Thus, various policies throughout the world lead to discipline integration in the curriculum. Based on various research results, the integrated curriculum has a positive correlation with student learning achievement when compared to traditional models (Yoon, Dyehouse, Lucietto, Diefes-dux, \& Capobianco, 2014). The benefits of an integrated curriculum can be seen internationally; countries that are at the top of the PISA scale all have policy provisions for integrated education (Drake \& Savage, 2016).

\section{Indonesian Curriculum}

Indonesia made a curriculum change from KTSP to curriculum 2013 (Retnawati, Munadi, Arlinwibowo, Wulandari, \& Sulistyaningsih, 2017; Zurqoni, Retnawati, Arlinwibowo, \& Apino, 2018). In its implementation, the curriculum 2013 had the same curriculum and textbook standards for all schools (Sigid \& Setiawan, 2018). The purpose of applying the curriculum 2013 is to improve the quality of learning and balance the development of students' attitudes, knowledge, and skills (Kartowagiran, Retnawati, Sutopo, \& Musyadad, 2017).

The first character of the curriculum 2013 is the use of a scientific approach in the learning process. The method of inquiry must be based on evidence from observable, empirical, and measurable objects (Ariyana et al., 2018). According to De Vito states that science is learning that adopts the steps of researchers to build knowledge through scientific methods. The learning model needed is a model that develops science thinking ability (Retnawati, 2015).

Teaching steps in the curriculum 2013 include: (a) introduction (greetings, summoning one by one, aperceptions, and motivating), (b) main parts (classics, groups, and individual learning), (c) evaluation (written tests, exercises, improvement and enrichment activities), and (d) Reflections (Sigid \& Setiawan, 2018). Scientific learning is carried out with the stages of asking, trying, associating, and communicating (Edelson, Gordin, \& Pea, 2011). To strengthen the scientific approach, according to Minister of Education and Culture Regulation No. 22 of 2016 concerning the standards of basic and secondary education processes, school is necessary to apply discovery/inquiry learning. To encourage the ability of students to produce contextual work, both individually and in groups, it is strongly recommended to use a learning approach that produces work based on problem solving (project based learning).

\section{STEM Integration in Curriculum 2013}

The first thing that will be solved is to adjust the implementation of STEM education with the Curriculum 2013. Various core components must be synchronized so that it becomes a mutually supportive entity. Learning in the Curriculum 2013 with a scientific approach through observing, questioning, gathering information, processing information, and communicating (Ariyana et al., 2018; Edelson et al., 2011). Whereas STEM education has two special characteristics namely the existence of engineering design (EDP) 
processes and project-based learning. EDP in learning includes steps starting with asking, imagining, planning, making, testing, and revising for product improvement (Lachapelle \& Cunningham, 2007; Susan \& Delaney, 2011; Syukri et al., 2017). Project-based learning must be filled with steps starting from asking questions, designing products, arranging schedules, making products, conducting trials, and evaluating learning experiences (Ariyana et al., 2018; Zancul, Sousa-zomer, \& Cauchick-miguel, 2017).

Table 1. Core of STEM Education Steps

\begin{tabular}{llll}
\hline & Scientific (Curriculum 2013) & & EDP (STEM) \\
\hline 1 & Observe & 1 & Ask \\
2 & Ask & 2 & Imagine \\
3 & Collect the information & 3 & Plan \\
4 & Process information & 4 & Create \\
5 & Communicate & 5 & Experiment \\
& & 6 & Improvement \\
\hline
\end{tabular}

The steps for implementing STEM education that is adjusted to the Curriculum 2013 is (1) Identify the problem is the initial stage of implementing STEM-based learning in the Curriculum 2013 is to identify problems. At this stage, students are directed to look at phenomena or events related to themes determined by the teacher. Through these observations, students are expected to be able to identify various problems that occur. Problems are questions that will be used as project directions in learning. (2) Planning a design to answer the problem. The design phase is done after the student is able to identify the problem and can focus on the particular problem to be studied. Thus, students are directed to gather various relevant information as a basis for making project designs. The design includes product design and scheduling design in implementing projects. The design began by making a product design based on student knowledge, then students make an estimate of the product manufacturing schedule. (3) Making products. Students realize the design that refers to the planning that has been prepared in the previous stage. (4) Trial of the product and evaluations. Products will be tested to know their quality. The results of the trial will produce various data that can be analyzed. That analysis result can be used as a material to conclude whether there is a need for improvement or not. (5) Revising the product based on the conclusion of the trial results so students focus on several sections to be revised. These improvements aim to make the product function better. (6) Summarizing and communicating findings. After the final product is declared final, students are directed to make conclusions based on the process that has been passed, including why revisions must be made. The teacher conditions students to be able to deduce the results of the project in the domain of science that is being targeted (Science, Technology, Engineering, and Mathematics). The findings were presented in front of other friends and carried out a discussion with each other.

In points 4 to 5 , it can be repeated steps to be able to produce the best product (if the revision is still not optimal). Next, the thing that must be considered is the STEM integration approach in the learning process in accordance with the curriculum. At present, the curriculum that applies in Indonesia is the Curriculum 2013 where the concept of learning in thematic elementary schools (for some thematic subjects) while junior and senior high schools use the concept of fragmentation between subjects. Thus the transdisciplinary approach is not suitable because it does not pay attention to every discipline. A suitable approach is multidisciplinary and interdisciplinary. They can still identify each discipline so that the final report on student learning outcomes for each subject can still be administered.

\section{Conclusions}

The literature review produces a learning syntax that aligns between EDP Steps in STEM, Scientific Method in Curriculum 2013, and project-based learning steps. The syntax of implementation STEM in Curriculum 2013 is identifying problems, designing designs to answer problems, making products, conducting product trials and evaluations, revising products, concluding and communicating findings. 
Cite this article as: Arlinwibowo, J., Retnawati, H., \& Kartowagiran, B. (2021). How to Integrate STEM Education in Indonesian Curriculum? A Systematic Review. Challenges of Science. Issue IV, 2021, pp. $18-25$. https://doi.org/10.31643/2021.03

\section{References}

Ariyana, Y., Pudjiastuti, A., Bestary, R., \& Zamroni. (2018). Buku pegangan pembelajaran berorientasi pada keterampilan berpikir tingkat tinggi [Learning handbook oriented to higher order thinking skills]. Jakarta: Kementerian Pendidikan dan Kebudayaan, Republik Indonesia.

Arlinwibowo, J., Retnawati, H., \& Badrun, K. (2020). The Types of STEM Education Implementation in Indonesia. Journal of Xi'an University of Architecture \& Technology, XII(VIII), 606-613.

Arlinwibowo, J., Retnawati, H., Hadi, S., Kartowagiran, B., \& Kassymova, G. K. (2021). Optimizing of item selection in computerized adaptive testing based on efficiency balanced information. Journal of Theoretical and Applied Information Technology, 99(4), 921-931.

Arlinwibowo, J., Retnawati, H., \& Kartowagiran, B. (2020). Model penilaian capaian belajar matematika dengan framework STEM [Assessment model of learning achievement in mathematics with the STEM framework ]. Yogyakarta: UNY Press.

Arlinwibowo, J., Retnawati, H., Kartowagiran, B., \& Kassymova, G. K. (2020). Distance learning policy in Indonesia for facing pandemic COVID-19: School reaction and lesson plans. Journal of Theoretical and Applied Information Technology, 98(14), 2828-2838.

Barak, M. (2012). Teaching engineering and technology: cognitive, knowledge and problem-solving taxonomies. Journal of Engineering, Design, and Technology, 11(3), 316-333. https://doi.org/10.1108/JEDT-04-2012-0020

Beane, J. A. (1995). Curriculum integration and the disciplines of knowledge. Phi Delta Kappan, 76(8), 616-622. https://doi.org/10.4324/9780203817568.ch20

Braun, V., \& Clarke, V. (2006). Using thematic analysis in psychology. Qualitative Research in Psychology, 3(2), 77-101. https://doi.org/10.1191/1478088706qp063oa

Bybee, R. W. (2010). Advancing STEM Education: A 2020 Vision. Technology \& Engineering Teacher, 70(1), 30-35.

Chesky, N. Z., \& Wolfmeyer, M. R. (2015). Philosophy of STEM Education. New York, NY: Palgrave Macmillan.

Corlu, M. S. (2013). Insights into STEM education praxis: An assessment scheme for course syllabi. Kuram ve Uygulamada Egitim Bilimleri, 13(4), 2477-2485. https://doi.org/10.12738/estp.2013.4.1903

Czerniak, C. M., Weber, W. B., Sandmann, A., \& Ahern, J. (1999). A Literature Review of Science and Mathematics Integration. Science and Mathematics Integration, 99(9), 421-430.

Drake, S. M., \& Burns, R. C. (2004). Meeting standards through integrated curriculum. Alexandria, VA: ASCD.

Drake, S. M., \& Reid, J. L. (2018). Integrated Curriculum as an Effective Way to Teach 21st Century Integrated Curriculum as an Effective Way to Teach 21st Century Capabilities. Asia Pacific Journal of Educational Research, 1(1), 31-50. https://doi.org/10.30777/APJER.2018.1.1.03

Drake, S. M., \& Savage, M. J. (2016). Negotiating Accountability and Integrated Curriculum from a Global Perspective. International Journal of Learning, Teaching and Educational Research, 15(6), 127-144.

Edelson, D. C., Gordin, D. N., \& Pea, R. D. (2011). Addressing the challenges of inquiry based learning through technology and curriculum design. The Journal of the Learning Science, 8(3\&4), 391-450. https://doi.org/http://dx.doi.org/10.1080/10508406.1999.9672075

Fu, Y., \& Sibert, S. (2017). Teachers' Perspectives: Factors That Integrated Curriculum in K-3 Classrooms Impact. International Journal of Instruction, 10(1), 169-186. https://doi.org/10.12973/iji.2017.10111a

Furner, J. M., \& Kumar, D. D. (2007). The mathematics and science integration argument: A stand for teacher education. Eurasia Journal of Mathematics, Science and Technology Education, 3(3), 185-189. https://doi.org/10.12973/ejmste/75397

Gehrke, N. J. (1998). A look at curriculum integration from the bridge. The Curriculum Journal, 9(2), 247-260. https://doi.org/10.1080/0958517970090209

Green, S. L. (2014). STEM Education: How to Train 21st Century Teachers. New York, NY: Nova Science Publisher.

Hernandez, P. R., Bodin, R., Elliott, J. W., Ibrahim, B., Rambo-Hernandez, K. E., Chen, T. W., \& De Miranda, M. A. (2014). Connecting the STEM dots: Measuring the effect of an integrated engineering design intervention. International Journal of Technology and Design Education, 24(1), 107-120. https://doi.org/10.1007/s10798-013-9241-0

Honey, M. A., Pearson, G., \& Schweingruber, H. (2014). STEM integration in K-12 education: status, prospects, and an agenda for research. In STEM Integration in K-12 Education: Status, Prospects, and an Agenda for Research. Washington, DC: The National Academies Press.

Kassymova G. (2018). Competence and its implications. Challenges of Science. https://doi.org/10.31643/2018.063

Kanematsu, H., \& Barry, D. M. (2016). STEM and ICT Education in Intelligent Environments. Cham, Switzerland: Springer.

Kenzhaliev B.K., Berkinbayeva A.N., Suleimenov E.N. (2014). Using sulfur graphite electrode for extracting metals from refractory materials. Proceedings of the 65th Annual Meeting of the International Society of Electrochemistry Ubiquitous Electrochemistry, (EUE'14), Lausanne, Switzerland.

Kenzhaliev B.K., Surkova T.Y., Yulusov S.B., Pirmatov E.A., Dulenin A.P. (2017). Polucheniye kontsentrata redkozemel'nykh elementov iz otkhodov i promproduktov uranovoy promyshlennosti [Obtaining a concentrate of rare earth elements from waste and industrial products of the uranium industry] Kompleksnoe Ispol'zovanie Mineral'nogo syr'â = Complex Use of Mineral Resources, Issue 1, pp. 70-77. (in Rus.). 
Kartowagiran, B., Retnawati, H., Sutopo, \& Musyadad, F. (2017). Evaluation of the Implementation of Curriculum 2013 Vocational. The 5th International Conference On Education Research and Innovation, 814-819. Yogyakarta.

Katehi, L., Pearson, G., \& Feder, M. (2009). Engineering in K-12 Education : Understanding the Status and Improving the Prospects. Washington, DC: The National Academies Press.

Kelley, T. R., \& Knowles, J. G. (2016). A conceptual framework for integrated STEM education. International Journal of STEM Education, 3(11), 1-11. https://doi.org/10.1186/s40594-016-0046-z

Khaeroningtyas, N., Permanasari, A., \& Hamidah, I. (2016). Stem learning in material of temperature and its change to improve scientific literacy of junior high school students. Jurnal Pendidikan IPA Indonesia, 5(1), 94-100. https://doi.org/10.15294/jpii.v5i1.5797

Lachapelle, C. P., \& Cunningham, C. M. (2007). Engineering is Elementary: Children's Changing Understandings of Science and Engineering. Proceedings of the 2007 American Society for Engineering Education Annual Conference \& Exposition Copyright, 1-33. Museum of Science, Boston.

Lonning, R. A., Defranco, T. C., \& Weinland, T. P. (1998). Development of Theme-based, Interdisciplinary, Integrated Curriculum: A Theoretical Model. A Theoretical Model. School Science and Mathematics, 98(6), 312-319.

Marsigit, M., Retnawati, H., Apino, E., Santoso, R. H., Arlinwibowo, J., Santoso, A., \& Rasmuin, R. (2020). Constructing Mathematical Concepts through External Representations Utilizing Technology : An Implementation in IRT Course. TEM Journal, 9(1), 317326. https://doi.org/10.18421/TEM91

NBPTS. (2016). Science Standards for Teacher of Students ages 11-18+ (3rd ed.). Arlington, VA: NBPTS.

NCTM. (2000). Principles and Standards for School Matematics. Reston, VA: NCTM.

Ntemngwa, C., \& Oliver, J. S. (2018). The implementation of integrated science technology, engineering and mathematics (STEM) instruction using robotics in the middle school science classroom. International Journal of Education in Mathematics, Science and Technology, 6(1), 12-40. https://doi.org/10.18404/ijemst.380617

Putra, D. P. A. (2017). Educational Game for STEM Education in Indonesia Local Wisdom. Japan Society for Science Education, 31(8), 97-100.

Retnawati, H. (2015). Hambatan Guru Matematika Sekolah Menengah Pertama dalam Menerapkan Kurikulum Baru [Barriers to Middle School Mathematics Teachers in Implementing the New Curriculum]. Cakrawala Pendidikan, XXXIV(3), 390-403.

Retnawati, H., Munadi, S., Arlinwibowo, J., Wulandari, N. F., \& Sulistyaningsih, E. (2017). Teachers' difficulties in implementing thematic teaching and learning in elementary schools. The New Educational Review, 48(2), $201-212$. https://doi.org/10.15804/tner.2017.48.2.16

Roehrig, G. H., Wang, H., Moore, T. J., \& Park, M. S. (2012). Is Adding the E Enough? Investigating the Impact of K-12 Engineering Standards on the Implementation of STEM Integration. School Science and Mathematics, 112(1), 31-44.

Rosicka, C. (2016). From concept to classroom Translating STEM education research into practice. Camberwell, Victoria: Australian Council for Educational Research.

Shahali, E. H. M., Halim, L., Rasul, M. S., Osman, K., \& Zulkifeli, M. A. (2017). STEM Learning through Engineering Design : Impact on Middle Secondary Students ' Interest towards STEM. EURASIA Journal of Mathematics Science and Technology Education, 13(5), 1189-1211. https://doi.org/10.12973/eurasia.2017.00667a

Sigid, M., \& Setiawan, C. (2018). Phenomenological Study of Experience and Meaning on K-13 Implementation by Elementary Physical Education Teacher in Purworejo Regency. Advances in Social Science, Education and Humanities Research, 278, 7681. Yogyakarta: Atlantis Press.

Susan, H., \& Delaney, M. (2011). An Educator's Guide to the Engineering Design Process Grades 6-8. Retrieved from https://www.nasa.gov/pdf/630754main_NASAsBESTActivityGuide6-8.pdf

Syukri, M., Halim, L., \& Mohtar, L. E. (2017). Engineering Design Process: Cultivating Creativity Skills through Development of Science Technical Product. Jurnal Fizik Malaysia, 38(1), 55-65.

Wisudawati, A. W. (2018). Science Technology Engineering and Mathematics (STEM) Education Aproach against a misroscopic representation skill in atom and molecule concept. International Journal of Chemistry Education Research, 2(1), 1-5.

Yoon, S. Y., Dyehouse, M., Lucietto, A. M., Diefes-dux, H. A., \& Capobianco, B. M. (2014). The Effects of Integrated Science, Technology, and Engineering Education on Elementary Students' Knowledge and Identity Development. School Science and Mathematics, 114(8), 380-391. https://doi.org/htps://doi.org/10.1111/ssm.12090

Zancul, E. de S., Sousa-zomer, T. T., \& Cauchick-miguel, P. A. (2017). Project-based learning approach: improvements of an undergraduate course in new product development. Production, 27(Special), 1-14. https://doi.org/10.1590/01036513.225216

Zinn, B. (2014). Technological literacy - Relevance spectrum, educational standards and research prespectives. Journal of Technical Education, 2(2), 1-23.

Zurqoni, Retnawati, H., Arlinwibowo, J., \& Apino, E. (2018). Strategy and implementation of character education in senior high schools and vocational high schools. Journal of Social Studies Education Research, 9(3), $370-397$. https://doi.org/10.17499/jsser.01008 